\title{
A NOTE TO TEACHERS
}

What better way to learn about anthropology and how anthropologists practice it than to study one of the discipline's great controversies? It is all here: crucial intellectual and professional questions that confront the discipline, the practical politics of being an anthropologist, and where we go from here as a discipline.

The way anthropology and anthropologists are sometimes presented in textbooks brings to mind the Wizard of $\mathrm{Oz}$. We perceive anthropology (like the wizard) as it wishes to present itself-in ways that inspire awe and respect. Yanomami: The Fierce Controversy and What We Can Learn from It lets readers step behind the screen the discipline presents to the world. We gain a sense of what anthropologists, in fact, are like: how they conduct fieldwork, grapple with difficult issues, and live professional lives. One sees the discipline's very human side, up close and clear.

The book is directed at two audiences. Introductory students can read part I as a way of "getting their feet wet" with the discipline-learning anthropology by being anthropologists in how they evaluate issues. It is slightly more than a hundred pages and can be read in one week. It provides an overview of the controversy as well as a discussion of the central issues at stake in it. Rather than being told what to think, students have an opportunity to think for themselves about a set of critical disciplinary issues.

Advanced students concerned with contemporary issues - from ethics, research methods, and the uses (and misuses) of ethnography to theory and the discipline's present (and future) dynamics - will also find much food for thought. The book is not only about how anthropologists engage with "others" but about how anthropologists act as a discipline, how they engage with one another - the anthropology of anthropology. Part 2 includes an extended discussion by six experts of the issues at stake in the Yanomami controversy. It constitutes the fullest, most open discussion of the controversy to date. Students are encouraged to wend their way through the various arguments and counterarguments and come to their own conclusions. The last chapter draws students into assessing the discipline and deciding where we might go from here.

Yanomami: The Fierce Controversy and What We Can Learn from It is not meant simply to be read. It is meant to foster discussion and, through that discussion, insight into how anthropology reproduces itself as a discipline. For example, stu- 
dents might explore the questions raised in chapter 6 in small groups and then bring their answers back to the larger class for discussion. They might take a particular issue - such as informed consent or just compensation — and develop a class position on it. They might also reenact the part 2 discussion with its arguments and counterarguments.

Embedded in the text are a number of student aids. A personal note to undergraduates suggests how they might effectively read the book, especially the part 2 discussion. A list of movies relating to the Yanomami is provided for teachers to consider showing in class or to have students watch on their own as a supplement to the book. In addition, each section of chapters 8, 9, and io presents key points and questions to help clarify that section's arguments. And questions are set out in chapter 6 for students to ponder. Of critical importance is the Public Anthropology Web site (www.publicanthropology.org), where students can gain additional information and, critically, can help foster change.

In using this book, then, students gain insight into

- the practice of modern-day anthropology, not only as an abstraction but as a reality embodied in a controversy with real people;

- the disciplinary dynamics that shape (and reshape) the anthropological enterprise through time;

- ethical and professional dilemmas that lie at the heart of the discipline today; and

- the excitement of anthropology as a field - as something not only to read but also to participate in actively. 